\title{
Recognizing the Role of Job Satisfaction in Predicting the Relationship Between Political Organization, Organizational Climate, and Organizational Culture on Organizational Citizenship Behaviour on Liquor Distributor Companies in Indonesia
}

\author{
Mochamad Soelton* \\ Management Department, Faculty of Economics and Business \\ Universitas Mercu Buana, Indonesia \\ Noermijati Noermijati \\ Management Department, Faculty of Economics and Business \\ Universitas Brawijaya, Indonesia \\ Nicko Alexander Vizano \\ Management Department, Faculty of Economics and Business \\ Universitas Mercu Buana, Indonesia \\ Yenida Parmariza \\ Management Department, Faculty of Economics and Business \\ Universitas Mercu Buana, Indonesia \\ Yudha B. Abadi \\ Management Department, Faculty of Economics and Business \\ Politeknik Sahid, Indonesia \\ Shandra Zulfriadi \\ Management Department, Faculty of Economics and Business \\ Universitas Mercu Buana, Indonesia
}

\begin{abstract}
This study aims to examine and analyze the influence of Political Organization, Organizational Climate, and Organizational Culture on Organizational Citizenship Behavior (OCB) with Job Satisfaction as an intervening variable at Liquor Distributor. The object of this research is the employees of Liquor Distributor as many as 45 respondents. The approach used in this research is the Component or Variance Based Structural Equation Model with Smart-PLS analysis tools. The results Showed that the Political Organization had no significant effect on Job Satisfaction on the employees of Liquor Distributor. Organizational Climate has a significant positive effect on Job Satisfaction on Liquor Distributor. Organizational Culture has a significant positive effect on Job Satisfaction on Liquor Distributor. Political Organizational positive significant effect on Organizational Citizenship Behavior (OCB) on employees of Liquor Distributor Organizational Climate has a significant positive effect on Organizational Citizenship Behavior (OCB) for employees of Liquor Distributor. Significantly positive effect Organizational Culture on Organizational Citizenship Behavior (OCB) on employees of Liquor Distributor. Job Satisfaction has a significant positive effect on Organizational Citizenship Behavior (OCB) for employees of Liquor Distributor.

Keywords: Political Organization, Organizational Climate, Organizational Culture, Organizational Citizenship Behavior. Job satisfaction

DOI: $10.7176 / \mathrm{EJBM} / 12-13-08$

Publication date:May $31^{\text {st }} 2020$

\section{INTRODUCTION}

The business world is experiencing rapid growth resulted in the need for a Human Resources (HR) qualified and competent continues to increase in order to achieve organizational goals that have been set. Human resources need to be managed and nurtured properly so that they can carry out their work as possible so that employees contribute optimally to do a good job. The company's role in the realization of what the expectations and demands of employees in the work, then the work will feel satisfying for employees (Soelton, 2018), (Ramli et al, 2019) and (Jumadi et al, 2018), (Saranya, 2014).
\end{abstract}


Morehead and Griffin (2013) stated OCB refers to the behavior of individuals who make a positive contribution to the organization. Novliadi (2017) states the expected behavior by an organization is not only inrole behavior (point a and point b), but also the role of extra behaviour (point c). Extra role behavior is called Organizational Citizenship Behavior (OCB). OCB very useful for companies with voluntary attitude that employees will affect the effectiveness of the organization. Leaders within the organization should set an example and consider the factors that may affect the OCB. Factors that influence to cause OCB attitude includes factors from within and outside of the individual. Attitude voluntary and optional behavior is not part of the formal task of a person, but nevertheless what the person and lead to improvements in the effectiveness of the task and role of the organization (Applebaum et al., 2004). Employees who do not have high job satisfaction tend to be involved with Organizational Citizenship Behavior within the company. Low OCB employees will affect the progress of the organization, where employees were not contributed to the company and work carelessly Nurhayati et al, (2017), Kusumajati, (2014).

According to Fox et al. (2011) OCB considered a performance that supports social and psychological environment in which the task performance occurs. Soelton and Rakasidhi (2018) states this behavior illustrates the added value of employees, which is one form of behavior that proposial positive social behavior, constructive and meaningful. Based on interviews conducted with some of the employees and human resource department of Liquor Distributor has not seen the behavior of employees who work in excess of the required tasks. Employees are still concerned with each other's work and did not show a sense of care for the work of colleagues in the company. Most employees are not satisfied with the results obtained, as well as working conditions which are not in harmony among colleagues to help each other and work colleagues tend to work individually. OCB behavior is not listed directly on employee job description, but is expected because this behavior is a positive influence on the sustainability of the organization (Podsakoff et al, 2000). Absenteeism that occurs triggered by job dissatisfaction felt by employees, so job satisfaction is described as an attitude resulting from the balance and the number of likes and dislikes experienced in connection with the work (Bullock, 2003).

Low job satisfaction affects the employee for not participating in the organization of cultural activities of companies that run every year. Job satisfaction is well aligned with the organization's culture. Job satisfaction is considered as an unpleasant emotional state and in which employees view their jobs (Widoto, 2006). If the employee perceptions of organizational culture of both the employee will be satisfied with his work. Organizational culture consists of values and norms that are shared by employees on how they should look, think, feel and behave in connection with organizational issues (Hartnel et al ,. 2016).

Political behavior at Liquor Distributor is unavoidable given the level of competition within the organization is often found. Employee actions lead to personal interests without regard to the interests of other employees and the most important thing is to get more attention in front of the leadership of the organization, so it is very rare to find an initiative to help voluntarily in the organization. Organizational politics makes it possible to produce positive and negative work (Fairuzzabadi, et al., 2016).

Behavior of employees who are not cooperative in the organization will make it difficult for the organization to achieve company goals. The organization will not succeed if the employee only does his main tasks but is also willing to do extra work. So that the work atmosphere is not formed properly, it will reduce unity within the organization to cause mutual assistance between employees. Organizational climate as a psychological tool for focusing on individuals and trying to understand cognitive and behavioral development (Davidson, 2003).

\section{MATERIALS AND METHODS}

Human Resources Management

According Rival \& Sagala (2011) Human Resource Management (HRM) is one of the areas of general management that includes aspects of planning, organizing, implementation and control. According Larasati (2018) Human Resources (HR) is a central factor in an organization, regardless of the form and purpose, the organization is based on a wide range of vision, mission, and goals for the benefit of man, so man is a strategic factor in all activities of the institution / organization. According Sutrisno (2017) Management of human resources are the only resources of the sense of feeling, keingininan, skills, knowledge, encouragement, power and work (ratio, taste, and intention).

\section{Organizational Citizenship Behavior}

Organ (1997) defines Organizational Citizenship Behavior (OCB) as a behavior that is the choice and individual initiative, not related to the formal reward system of the organization remains in the aggregate to improve the effectiveness of the organization. Meanwhile Dyne, et al (1995), which proposes the construction of Citisenship Organizational Behavior (OCB), which is favorable behavior or funding organizations tend to benefit the organization, voluntarily and exceeds what the demands of the role. According to Titisari (2014) Dimensions of Organizational Citizenship Behavior (OCB), that is :

- Altruism - Replacing co-workers who don't go in or resting, helping others overload, helping others outside the department when they have problems. 
- Conscientiousness - Arrive early, so be ready to work when the schedule starts, Be on time every day, Don't spend time talking outside of work.

- Sportmanship - Not finding fault in the organization, Not complaining about everything, Not exaggerating problems beyond proportion.

- Courtesy - Involvement in organizational functions, Give attention to functions that help the image, Respect the privacy and rights of co-workers.

- Civic Virtue - Follow the changes, Participate in various activities organized by the organization, Provide innovative advice to improve the quality of the organization.

\section{Job Satisfaction}

Sutrisno (2011) suggested the job satisfaction is an emotional state that is pleasant or unpleasant for the employee view their job. Meanwhile, according Suhendi\&Anggara (2010) job satisfaction is an attitude (positive) labor to the job, which comes under the assessment of the employment situation. Furthermore Badriyah (2015) argued that the definition of job satisfaction according to Badriyah Mila is the attitude or feelings of employees on aspects of a pleasant or unpleasant about work in accordance with the assessment of each worker. According to Luthans (2011) the factors used to measure job satisfaction are :

- Job itself - The extent to which individuals learn, take responsibility for the work received, elements of satisfaction in work.

- Salary / Wages - The amount of financial remuneration received, to the extent seen as equivalent to the others, the suitability of wages received.

- Promotion Opportunities - Opportunities are accepted for organizational progress, promotion, promotion as employee motivation to progress.

- Supervision - Ability possessed by supervisors to assist employees, Ability possessed by supervisors to support employees, Supervision of work.

- Co-workers -Co-worker skills, Supporting individuals socially, harmonious relationships.

\section{Political Organization}

Sunyoto and Burhanuddin (2011) Political organization can be defined as an increase in personal interest deliberate. Political organizations involve measures to to influence that is done intentionally to improve or protect the personal interests of individuals or groups. Individuals who join an organization faced with a choice, namely the pursuit of personal interests or to achieve organizational goals. Meanwhile, according to Robbins and Judge (2011) political behavior is defined as activities that are not considered part of the formal role of a person in the organization. According to Chen \& Fang (2008) stated organizational politics has three dimensions, that is :

- Organizational practices and policies - Done by developing themselves in the organization by bringing down other people, determining certain positions or positions determined by political interests, more saying what you want to hear is not the truth.

- Colleagues behavior - Done by offering help because there is a hidden purpose, Showing goodness only to show a positive image, Saving / distorting information requested by other colleagues.

- Go along to get ahead - By way of freedom of speech even though it is contrary to standard rules, a good idea is allowed even if it is contrary to the majority's idea. Organizational politics is used as a tool to achieve something that is desired.

\section{Organizational Climate}

Wirawan (2007) Organizational climate is the perception of organizational members (individual and group) and those who are staying in touch with the organization (eg, suppliers, customers, consultants, and contractors) as to what is or happens in the internal environment of the organization routinely affecting attitude organizational behavior and performance of members of the organization which then determines the performance of the organization. Tagiuri and Litwin (1968) defines climate as the organization's internal environment quality organization that is relatively continuing experienced by members of the organization and can be described in terms of a set of characteristics on the nature of the organization.

According to Wirawan (2007) outlining a number of examples of organizational climate dimensions, that is :

- State of the physical environment - Workplace, Furniture, Production Equipment and so on.

- Social environment - Relationship between superiors and subordinates, Relationships between coworkers, Cooperation in carrying out tasks

- Implementation of management systems - Organizational structure, Work standards, Work procedures

- Physical and psychological condition of organization members - Agility, Health, Togetherness

- Organizational culture - Implementation of norms, Implementation of code of ethics, Organizational history

Organizational Culture

Schein (2010) states the organization's culture is the basic pattern received by the organization to act and solve problems, form the staff who are able to adapt to the environment and to unite the members of the organization. Organizational culture by Wirawan (2007) are the norms, values, assumptions, beliefs, philosophy, customs 
organizations, and so on, the founders, leaders and members of the organization are socialized and taught to new members as well as applied in the organization's activities that affect the mindset, attitude and the behavior of members of the organization in serving customers, and achieve organizational objectives. According to Robbins and Judge (2017) there are seven primary characteristics that collectively capture the nature of organizational culture, that is :

- Innovation and risk taking - Having an innovative attitude, Daring to take risks must exist within the organization, Encouraged to be innovative.

- Attention to details - In the organization must pay attention to all provisions and analysis, Pay more attention to things around, Carry out the task carefully and precisely

- $\quad$ Results orientation - Focus on the final result, Develop the potential for the final result, Effectiveness of the final result.

- People orientation - The extent to which management decisions take into account the effect of results on people in the organization, Carry out tasks according to procedures, Take advantage of opportunities that exist.

- Team orientation - The ability of teamwork, does not work individually, helps or helps between employees.

- Aggressiveness - Individuals in the organization have a competitive attitude, work to be aggressive towards work, consistent with work.

- Stability - Working in accordance with the current state of the organization, Maintaining the status quo to develop and progress, the environmental conditions of the organization.

\section{Figure 1}

\section{Research Paradigm}

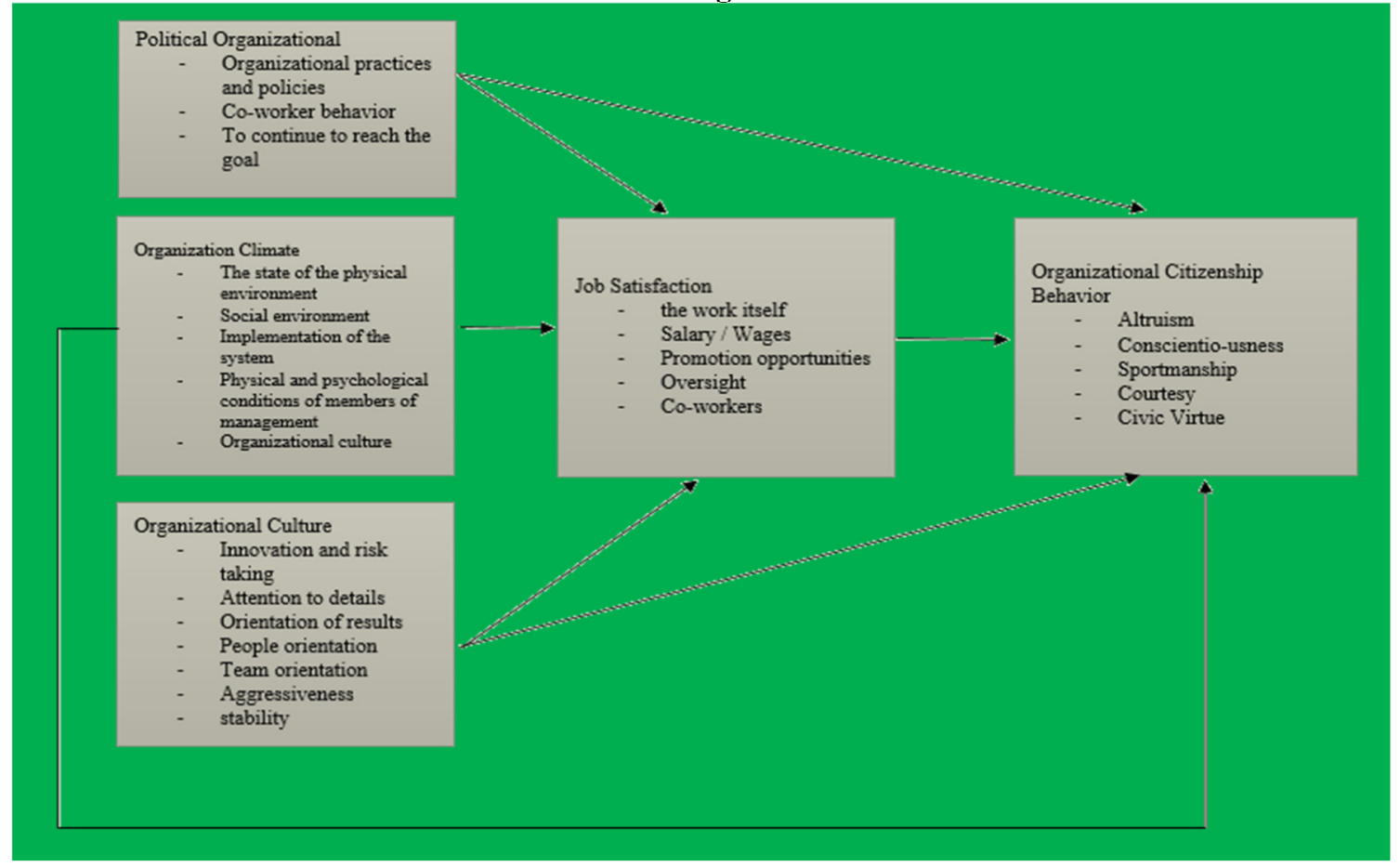

\section{Research Methods}

Measurement scale

In this study, the method of measurement using a likert scale used to measure attitudes, opinions and perceptions person or a group of social phenomenon Sugiyono (2017).

\section{Population and Sample Research}

According Sugiyono (2017), the sample is part of the number and characteristics possessed by this population. Methods of sampling using non-probability sampling that the sampling technique does not provide the opportunity or equal opportunity for each element or member of the population to be selected into the sample (Sugiyono, 2017). Determination of the samples used in this study using a type of saturated sample method. According Sugiyono (2017), the sample is saturated sampling technique when all members of the population used as a sample, it is often done when a relatively small number of the population. Another term saturated sample census, where all members of the population sampled. Samples far too often defined maximum sample already, plus whatever will not change the representation. Thus this study used a sample of 45 respondents with the status of employees of Liquor Distributor as the total population of employees with 45 employees, by providing questionnaires to 
employees or employees of Liquor Distributor.

\section{Data types}

The data used in this study are primary data. The primary source of data is the data obtained, it was observed, and recorded immediately by researchers directly from the company that became the object of research. Primary data in this study is a questionnaire data from Liquor Distributor.

\section{RESULTS AND DISCUSSIONS}

Table 1: Validity Test Results

\begin{tabular}{|c|c|c|c|}
\hline Variabel & Indikator & Outer Loading & Keterangan \\
\hline \multirow{7}{*}{ Political Organization } & PO1 & 0.765 & Valid \\
\hline & $\mathrm{PO} 2$ & 0.690 & Valid \\
\hline & $\mathrm{PO} 4$ & 0.774 & Valid \\
\hline & PO5 & 0.538 & Valid \\
\hline & PO6 & 0.768 & Valid \\
\hline & PO7 & 0.635 & Valid \\
\hline & PO9 & 0.789 & Valid \\
\hline \multirow{11}{*}{ Organizational Climate } & $\mathrm{OC} 4$ & 0.742 & Valid \\
\hline & OC5 & 0.555 & Valid \\
\hline & OC6 & 0.609 & Valid \\
\hline & OC7 & 0.624 & Valid \\
\hline & OC8 & 0.724 & Valid \\
\hline & OC9 & 0.757 & Valid \\
\hline & OC10 & 0.767 & Valid \\
\hline & OC11 & 0.565 & Valid \\
\hline & $\mathrm{OC} 12$ & 0.786 & Valid \\
\hline & $\mathrm{OC} 13$ & 0.663 & Valid \\
\hline & OC14 & 0.549 & Valid \\
\hline \multirow{15}{*}{ Organizational Culture } & $\mathrm{O} 1$ & 0.801 & Valid \\
\hline & $\mathrm{O} 2$ & 0.562 & Valid \\
\hline & $\mathrm{O} 3$ & 0.732 & Valid \\
\hline & $\mathrm{O} 4$ & 0.590 & Valid \\
\hline & O5 & 0.789 & Valid \\
\hline & O7 & 0.755 & Valid \\
\hline & O8 & 0.619 & Valid \\
\hline & O9 & 0.792 & Valid \\
\hline & $\mathrm{O} 12$ & 0.793 & Valid \\
\hline & $\mathrm{O} 13$ & 0.618 & Valid \\
\hline & $\mathrm{O} 14$ & 0.680 & Valid \\
\hline & $\mathrm{O} 17$ & 0.539 & Valid \\
\hline & O19 & 0.637 & Valid \\
\hline & $\mathrm{O} 20$ & 0.602 & Valid \\
\hline & $\mathrm{O} 21$ & 0.801 & Valid \\
\hline
\end{tabular}




\begin{tabular}{|cccc|}
\hline Variabel & Indikator & Outer Loading & Keterangan \\
\hline JS1 & 0.685 & Valid \\
JS2 & 0.628 & Valid \\
JS3 & 0.593 & Valid \\
JS4 & 0.684 & Valid \\
& JS5 & 0.590 & Valid \\
& JS6 & 0.668 & Valid \\
JS7 & 0.752 & Valid \\
& JS8 & 0.732 & Valid \\
& JS9 & 0.656 & Valid \\
& JS10 & 0.825 & Valid \\
JS11 & 0.739 & Valid \\
JS15 & 0.582 & Valid \\
\hline OCB1 & 0.669 & Valid \\
& OCB2 & 0.694 & Valid \\
& OCB3 & 0.751 & Valid \\
& OCB4 & 0.651 & Valid \\
Organizational Citizenship & OCB5 & 0.704 & Valid \\
Behaviour & OCB6 & 0.542 & Valid \\
& OCB10 & 0.777 & Valid \\
& OCB11 & 0.809 & Valid \\
& OCB14 & 0.808 & Valid \\
& OCB15 & 0.730 & Valid \\
& & &
\end{tabular}

Source: From Data Processing (2019)

Table 1 can be seen that all indicators have met the convergent validity because it has a laoading factor value exceeding 0,50 . so all the items used to measure the said variables are considered as valid. The reliability test of this research data is using Cronbach's Alpha coefficient method. The Cronbach's Alpha coefficient is the reliability coefficient that are most commonly used because the coefficient will indicate the variance of items with either correct or incorrect format such as Likert scale format.

The criteria of determining a valid item and having a reliable value that can be accepted are based on the table described below

Tabel 2: Standard Composite Reliability \& Cronbach's Alpha

\begin{tabular}{lccc}
\hline \multicolumn{1}{c}{ Variable } & $\begin{array}{c}\text { Cronbach } \\
\text { Alpha's }\end{array}$ & $\begin{array}{c}\text { Composite } \\
\text { Reliability }\end{array}$ & Description \\
\hline Political Organization & 0.802 & 0.850 & Reliabel \\
Organizational Climate & 0.877 & 0.900 & Reliabel \\
Organizational Culture & 0.900 & 0.916 & Reliabel \\
Job Satisfaction & 0.893 & 0.912 & Reliabel \\
Organizational Citizenship Behaviour & 0.869 & 0.896 & Reliabel \\
\hline
\end{tabular}

Source: From Data Processing (2019)

The result of the above calculation of the score items with the total based on the table above has a reliability coefficient Cronbach Alpha's value which is greater 0,7 which means that all instruments can be classified as reliable. 
Figure 2: The Correlation of Variables

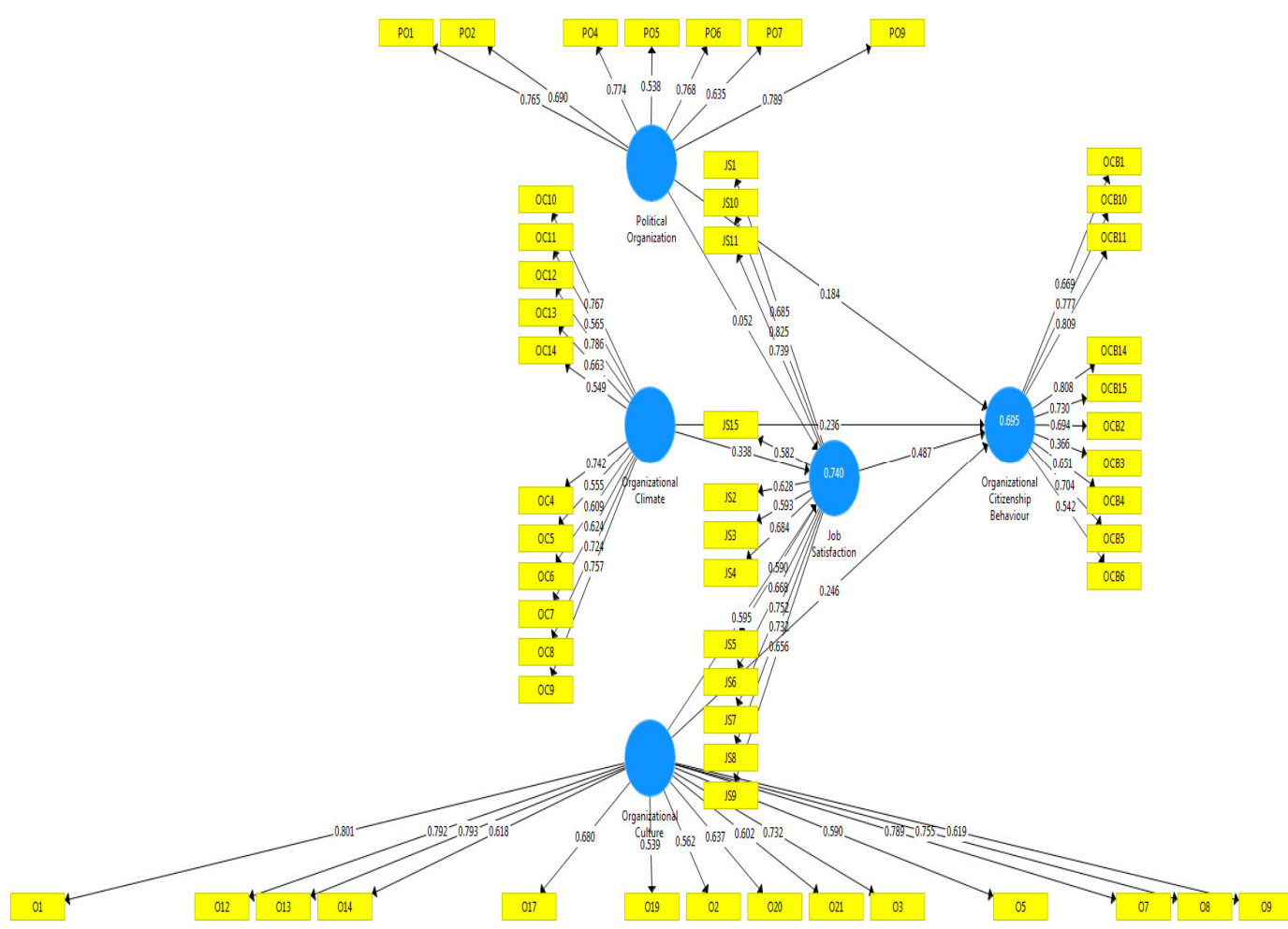

Source: From Data Processing (2019)

The measurement model of analysis above shows the link between manifest variables (indicators) and each of the latent variables. The analysis of the measurement model is to test the validity and reliability of each of the dimensions and the indicators utilized to measure the variables constructed earlier. The analysis of the measurement model describe that the value of discriminant validity is by looking at the value of square root of Average Variance Extracted (AVE) with the suggestion value above 0,5, loading factor $(>0.5)$, and constructed Composite Validity and Reliability (Cronbach's Alpha $>0.70$ ). Therefore, the conclusion of the dimensions and indicators which are classified as reliable earlier are showed below

Table 3: Goodness of Fit Model (GoF)

\begin{tabular}{|l|c|}
\hline \multicolumn{1}{|c|}{ Endogenous variables } & R-square \\
\hline Job Satisfaction & 0.740 \\
Organizational Citizenship Behavior & 0.695 \\
\hline
\end{tabular}

Source: From Data Processing (2019)

Predictive relevance value is obtained by the formula :

$\mathrm{Q}^{2}=1-(1-\mathrm{R} 1)\left(1-\mathrm{R}_{\mathrm{p}}\right)$

$\mathrm{Q}^{2}=1-(1-0.740)(1-0.695)$

$\mathrm{Q}^{2}=1-(0.260)(0.305)$

$\mathrm{Q}^{2}=0.9207$

The results of the above calculation evaluate the predictive value of greatest relevance 0.9207 which is greater than 0 (zero). That means that $92.07 \%$ on job satisfaction and organizational citizenship behavior (dependent variable) expected by the dependent variable used. Thus the model expected to have a relevant predictive value. 
Table 4: Hypothesis Testing Results

\begin{tabular}{|lccccc|}
\hline & $\begin{array}{c}\text { Original } \\
\text { Sample }\end{array}$ & $\begin{array}{c}\text { Standard } \\
\text { Deviation }\end{array}$ & T-Statistics & P Values & Keterangan \\
\hline $\begin{array}{l}\text { Political } \\
\text { Organizational } \rightarrow \text { Job } \\
\text { Satisfaction }\end{array}$ & 0.052 & 0.099 & 1.816 & 0.604 & Not Significant \\
\hline $\begin{array}{l}\text { Organizational } \\
\text { Climate } \rightarrow \text { Job Satisfaction }\end{array}$ & 0.338 & 0.106 & 3.192 & 0.002 & $\begin{array}{c}\text { Positive - } \\
\text { Significant }\end{array}$ \\
\hline $\begin{array}{l}\text { Organizational Culture } \\
\rightarrow \text { Job Satisfaction }\end{array}$ & 0.595 & 0.118 & 5.590 & 0.000 & $\begin{array}{c}\text { Positive - } \\
\text { Significant }\end{array}$ \\
\hline $\begin{array}{l}\text { Political Organizational } \rightarrow \\
\text { OCB }\end{array}$ & 0.184 & 0.201 & 2.519 & 0.010 & Positive- Significant \\
\hline $\begin{array}{l}\text { Organizational Climate } \rightarrow \\
\text { OCB }\end{array}$ & 0.236 & 0.198 & 2.259 & 0.001 & Positive- Significant \\
\hline $\begin{array}{l}\text { Organizational Culture } \rightarrow \\
\text { OCB }\end{array}$ & 0.246 & 0.135 & 2.160 & 0.027 & $\begin{array}{c}\text { Positive - } \\
\text { Significant }\end{array}$ \\
\hline Job Satisfaction $\rightarrow$ OCB & 0.487 & 0.226 & 2.151 & 0.032 & Positif - Significant \\
\hline
\end{tabular}

Source: From data processing (2019)

From the results of hypothesis testing, it was political organizational not significant effect on job satisfaction and organizational climate has a positive and significant effect on job satisfaction. While organizational culture has a positive and significant effect on job satisfaction and political organizational positive significantly influence organizational citizenship behavior (OCB). Organizational climate has a positive and significant effect on organizational citizenship behavior (OCB). Organizational culture has a positive and significant effect on organizational citizenship behavior (OCB). Job satisfaction has a positive and significant effect on organizational citizenship behavior (OCB).

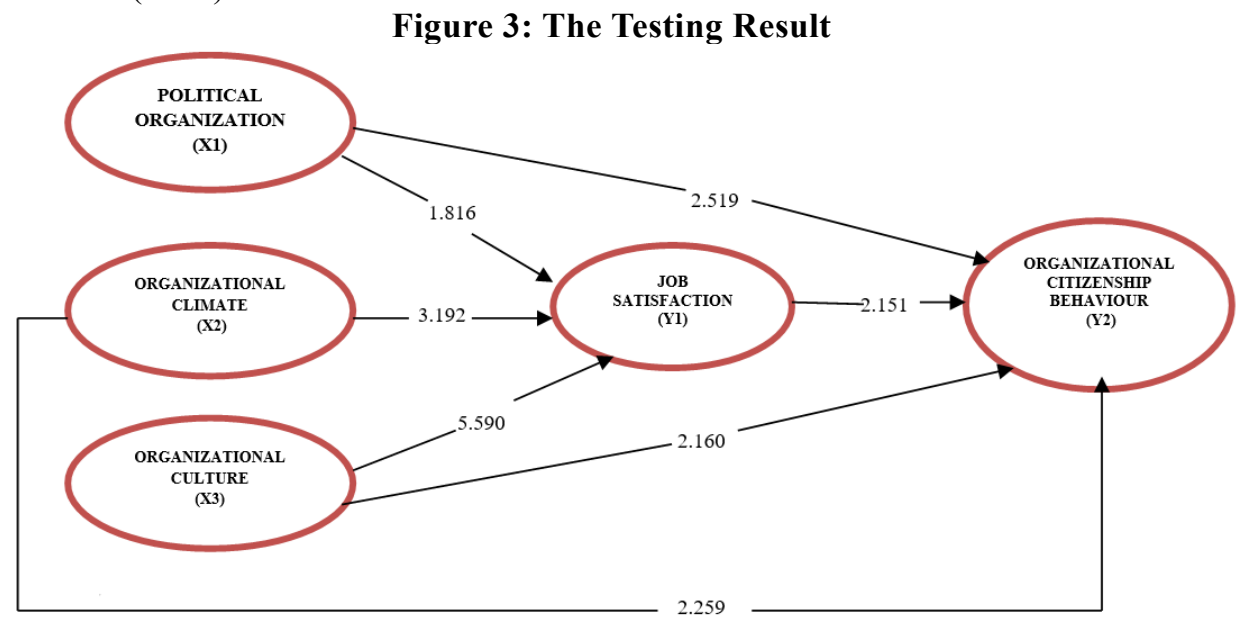

Source: Form data processing (2019)

Based on the testing result above, the research variables indicated that organizational culture has the most significant influence on job satisfaction as the intervening variable, which is 5.590 compare to the variable of political organization which is 1.816 and climate organization which is 3.192. Political organization also contributed influence towards organizational citizenship behavior with the figure of 2.519 compare to organizational climate 2.259 and organizational culture with the figure of 2.160. Even job satisfaction has a highest direct effect of against organizational citizenship behavior with the figure of 2.151 .

\section{DISCUSSIONS OF FINDINGS}

This study tries to analyze the variables related to political, organizational, organizational climate, organizational culture, job satisfaction, and organizational citizenship behavior (OCB). Results of this study was obtained from research on Liquor Distributor. From the results of the calculations in this study, it can be concluded as follows:

1. Political organizational no significant effect on job satisfaction in employees of Liquor Distributor. This means that if the good or bad of a political organization have no effect on employee job satisfaction.

2. Organizational climate significant positive effect on job satisfaction in employees of Liquor Distributor. This means that if a good organizational climate, it will increase employee job satisfaction.

3. Organizational culture significant positive effect on job satisfaction in employees of Liquor Distributor. This means that if the organizational culture in the company, the better, it will be increasing employee 
job satisfaction.

4. Political organizational significant positive effect on organizational citizenship behavior (OCB) at Liquor Distributor. This means that if politics within the organization goes well, it will be the employee will have an attitude of organizational citizenship behavior (OCB) is high.

5. Organizational climate significant positive effect on organizational citizenship behavior (OCB) at Liquor Distributor. This means that if the organizational climate in a good company, it will be the attitude of employees will create OCB

6. Organizational culture significant positive effect on organizational citizenship behavior (OCB) at Liquor Distributor. This means that if the organizational culture is good, it will improve the attitude of organizational citizenship behavior (OCB) employees.

7. Job satisfaction significant positive effect on organizational citizenship behavior (OCB) at Liquor Distributor. This means that if the higher employee satisfaction, the higher the attitude of organizational citizenship behavior (OCB) employees.

\section{REFERENCES}

Appelbaum, Steven \&Bartolomucci, Nicolas \&Beaumier, Erika \& Boulanger, Jonathan \& Corrigan, Rodney \& Dore, Isabelle \& Girard, Chrystine\&Serroni, Carlo (2004). organizational citizenship behavior : a case study of culture. leadership and trust management decision, Vol.42 No.1.

Ariyani, E, D. (2012). Dampak Iklim Organisasi terhadap Kepuasan Kerja. Manajeial, 11 (21), 132-149

Badriyah, M. (2015). Manajemen Sumber Daya Manusia, Cetakan 1. Bandung : CV Pustaka Setia.

Bullock, LM (2003): 'The Measurement of Organizational Commitment', Journal of Vocational Behaviour: 14: 224-247.

Chen, Yei-Yi and Fang W. 2008. The Moderating Effect of Impression Management on the Organizational Politics-Performance Relationship. Journal Of Business Ethics, 79, 263-277 congruence with culture dimensions during organizational transformation.

Davidson, M.C.G. (2003), “Does organizational climate add to service quality in hotels?", International Journal of Contemporary Hospitality Management, Vol. 15 No. 4, pp. 206-13.

El Badawy, T, A, Kamel, M, M, Maghdy, M, M. (2016). Exploring the Relationship between Organizational Culture, Job Satisfaction and Organizational Citizenship Behavior. International Journal of Human Resource Studies, 6 (4), 20-33, DOI : 10.529/ijrs.v6i4 9939. Empat.

Fairuzzabadi, Murkhana, \&Ayu, M, P. (2016). Pengaruh Politik Organisasional pada Kepuasan Kerja : Kepercayaan dan Dukungan Sosial sebagai Permoderasi. Jurnal Manajemen dan Inovasi , 7 (1), 1- 23.

Fox, S., Spector, P, E., Goh, A., Bruursema, K. and Kessler, S, R. (2011). The deviant citizen-measuring potential positive relations between counterproductive work behaviour and OCB.Journal of Occupational and Organizational Psychology, 85, 199-220.

Ghozali, Imam. (2014). Structural Equation Modeling, Metode Alternatif denganPartial Least Square (PLS). Edisi 4.Semarang :BadanPenerbitUniversitasDiponegoro.

Hartnell, Chad, A., Lambert, Lisa Schurer, Kinicki, Angelo J., Fugate, Mel, dan Corner, Patricia Doyle. (2016). Do Similarities or Differences Between CEO Leadership and Organizational Culture Have a More Positive Effect on Fimr Performance? A Testof Competing Predictions.Journal of Applied Psychology, 101(6), 846861.

Husudo, Y, R, P. (2018). PengaruhBudayaOrganisasiterhadap Organizational Citizenship Behaviour (OCB) dan Kepuasan Kerja Sebagai Variabel Intervening pada PT. Jatim Indo Lestari. Agora, 6 (1), 1-8.

Ibrahem, Soelton.,Rakadishi, Jaya. (2018). How to Implementation of Organizational Citizenship Behaviour with Performance on Accident Insurance Service.Europian Journal of Business and Management, Vol.10, No15.IISTE European Journal of Business and Management.

Kusumajati, D.A. (2014). Organizational citizenship behavior (OCB) karyawanpadaperusahaan X. Jurnal Humaniora, Vol.5, No.1 (62-70).

Larasati, S. (2018).ManajemenSumberDayaManusia. EdisiPertama, CV Budi Utama, Yogyakarta.

Luthans, F. (2011). Organizational Behaviour, Edition twelfth, McGraw-Hill/Irwin, New York.

Morehead dan Griffin (2013). Perilaku Organisasi: Manajemen Sumberdaya Manusia dan Organisasi (Organizational Behavior: Managing People and Organizations). Edisi 9. Jakarta: Salemba Empat.

Novliadi, Ferry. (2007). “Organizational Citizenship BehaviourKaryawanDitinjau Dari Persepsi terhadap Kualitas Interaksi Atasan - Bawahan Dan Psikologi Personalia”. Jakarta: Persepsi Terhadap Dukungan Rineka Cipta Organisasional"

Organ, D. W. (1997).Organiational Citizenship Behaviour: it's Construct Clean-up Time. Human Performance, $10,85-97$

Podsakoff, Philip. M.etal. 2000. Organizational Citizenship Behaviors: A Critical Review Of The Theoretical And Empirical Literature And Suggestions For Future Research. Journal Of Management, 26(3). 
Pradana, A, F, R., \& Triwijyati, D. (2016). Pengaruh Politik Organisasi dan Komitmen Organisasi terhadap Organizational Citizenship Behaviour Karyawan Koperasi Karyawan (KOPKAR) Sampoerna Surabaya. Jurnal Ilmu Manajamenen, 4 (2), 101-111.

Rivai, V. \&Sagala, E, J. (2011). Manajemen Sumber Daya Manusia untuk Perusahaan, Edisi Kedua, PT. Raja GrafindoPersada, Jakarta.

Robbins, S. P., \& Judge, T. A. (2011). Perilaku organisi (terj). Jakarta: Salemba

Robbins \& Judge (2017). Perilaku Organisasi, ( 1 st \& 2 nd Ed), Jakarta Penerbit Salemba Empat.

M Soelton, P Amaelia, H Prasetyo. 2020. Dealing with Job Insecurity, Work Stress, and Family Conflict of Employees.

4th International Conference on Management, Economics and Business (ICMEB 2019). 2020/2 (167-174). atlantis-press.com

M Soelton, D Amalia, N Noermijati, B Wahyudiono. 2020. Self-Esteem: The Levels of Religiosity in Job Insecurity and Stress in Government Company. 4th International Conference on Management, Economics and Business (ICMEB 2019). 2020/2 (302-310). atlantis-press.com

F Rohman, YB Abadi, M Soelton, N Prasetyo, ET Saratian. 2020. The Effect of Environmentally Friendly Paper Toward Purchasing Intention. 4th International Conference on Management, Economics and Business (ICMEB 2019). 2020/2 (120-126). atlantis-press.com

M Soelton, D Hardianti, S Kuncoro, J Jumadi. 2020. Factors Affecting Burnout in Manufacturing Industries. 4th International Conference on Management, Economics and Business (ICMEB 2019). 2020/2 (46-52). atlantispress.com

M Mugiono, BH Purwoko, M Soelton, R Yuvitasari. 2020. Recognizing How the Job Involvement, Burnout, and Self-Efficacy Work Influences the Work Stress at International Hospitals. 4th International Conference on Management, Economics and Business (ICMEB 2019). 2020/2 (264-270). atlantis-press.com

M Soelton, PA Lestari, H Arief, RL Putra. 2020. The Effect of Role Conflict and Burnout Toward Turnover Intention at Software Industries, Work Stress as Moderating Variables. 4th International Conference on Management, Economics and Business (ICMEB 2019). 2020/2 (185-190). atlantis-press.com

DF Suzabar, M Soelton, M Umar, J Triwulan. 2020. Recognizing How the Time Demands of Work Influences the Turnover Intention in Banking Industry. 4th International Conference on Management, Economics and Business (ICMEB 2019). 2020/2 (40-45). atlantis-press.com

A Nanda, M Soelton, S Luiza, ETP Saratian. 2020. The Effect of Psychological Work Environment and Work Loads on Turnover Interest, Work Stress as an Intervening Variable. 4th International Conference on Management, Economics and Business (ICMEB 2019). 2020/2 (225-231). atlantis-press.com

McShane, Steven L. and Mary Ann Von Glinow. Organizational Behavior. New York: McGraw-Hill, 2010.

Mobley, W. H. (2011). Pergantian Karyawan : Sebab, Akibat dan Pengendaliannya (Terjemahan). Jakarta: PT Pustaka Binaman Pressindo.

Moorhead, G., \& Griffin, R. (2013). Organizational Behavior: Managing People and Organization (9th ed.). Mason: SouthWestern Cengage Learning.

Nasution, M. I. (2017). Pengaruh Stres Kerja, Kepuasan Kerja Dan Komitmen Organisasi Terhadap Turnover Intention Medical Representative. MIX: Jurnal Ilmiah Manajemen, 7(3).

M Nurhayati, A Thoyib, DW Irawanto, 2019. Impersonal Trust and Perceived Organizational Politics on Organizational Commitment. European Research Studies Journal 21 (3), 391-403 | vol: | issue : 2018

M Nurhayatia, A Thoyib, N Noermijati, 2017. The Role of Political Skills for Organizational Commitment . International Journal of Economic Perspectives 11 (4), 493-498 | vol: | issue : | 2017

M Soelton, R Pratama. 2018. Effect of Recruitment Process, Selection, and Compensation on Frontliner Performance in Bank Industry. Proceeding International Conference on Management Economics and Business of Universitas Mercu Buana (ICMEB 2018). Jilid 2018. ISBN 978-979-99488-3-0

M Soelton, S Ria, F Arifin. 2018. Effect of Organizational Culture, Job Satisfaction, and Engagement on Employee Performance in Government Company. Proceeding International Conference on Management Economics and Business of Universitas Mercu Buana (ICMEB 2018). Jilid 2018. ISBN 978-979-99488-3-0

M Soelton, T Nugrahati, M Sholihin, Riyadhus. 2018. Effect of Work Stress and Workload on Labor Employee Performance in Aqua Danone Indonesia. Proceeding International Conference on Management Economics and Business of Universitas Mercu Buana (ICMEB 2018). Jilid 2018. ISBN 978-979-99488-3-0

M Soelton, L Yuliana. 2018. Effect of Organizational Culture, Organization Commitment, and Work Loyalty on Employee Performance in Manufacture Industry. Proceeding International Conference on Management Economics and Business of Universitas Mercu Buana (ICMEB 2018). Jilid 2018. ISBN 978-979-99488-3-0

M Soelton, D Sabartono. 2018. Effect of Recruitment Process, Selection, and Work Disciline on Employee Performance on Bakmi GM Jakarta. Proceeding International Conference on Management Economics and Business of Universitas Mercu Buana(ICMEB 2018) . Jilid 2018. ISBN 978-979-99488-3-0

M Soelton, A Daryadi. 2018. Effect on Compensation, Work Environment, Education, and Training on Employee 
Performance or Coffee Bean Outlets in Jakarta. Proceeding International Conference on Management Economics and Business of Universitas Mercu Buana (ICMEB 2018). Jilid 2018. ISBN 978-979-99488-3-0

Prajuanturi, Mardiki (2017). Pengaruh Kualitas Kehidupan Kerja dan Komitmen Organisasi terhadap Kinerja Karyawan di PT Agung Automall Cabang Soekarno Hatta Pekanbaru. JOM Fekon, Vol.4 No.2, Hal (22522263).

Rene, R., \& Wahyuni, S. (2018). Pengaruh work-life balance terhadap komitmen organisasi, kepuasan kerja, dan motivasi kerja terhadap kinerja individu pada karyawan perusahaan asuransi di jakarta. Jurnal Manajemen dan Bisnis Sriwijaya, 16(1), 53-63.

Robbins, Stephen P, and Judge, Timothy, A. 2015, Perilaku Organisasi, Edisi 16, Edisi Bahasa Indonesia, Terjemahan Ratna Saraswati dan Febriella Sirait. Salemba Empat, Jakarta.

Sebayang, S., \& Sembiring, J. (2017). Pengaruh Self Esteem Dan Self Efficacy Terhadap Kinerja Karyawan Studi Kasus Di Pt. Finnet Indonesia. eProceedings of Management, 4(1).

Sidharta, N., \& Margaretha, M. (2011). Dampak komitmen organisasi dan kepuasan kerja terhadap turnover intention: studi empiris pada karyawan bagian operator di salah satu perusahaan garment di Cimahi. Jurnal Manajemen, 10(2), 129-142.

Soelton, M., Nugrahati, T., Setiawan, M., Rochman, F., \& Pratama, A. (2019). Gender: Stress Levels on Performance in Modern Industry. Archives of Business Research, 7 (2), 72-81, DOI: 10.14738/abr.72.6131.

Soelton, M., Umar, M. (2018). Recognizing How The Time Demands of Work Influences the Turn Over Intention in Banking Industry. European Journal of Business and Management (EJBM), 12 (19)

Soelton, M. (2018). How Culture, Training Standard and Discipline on the Employee Performance Affect Hotel Management. European Research Studies Journal, 21(4), 378-385.

Soelton, M., \& Nugrahati, T. (2018). How Complaining Behaviors Effect on Coping Stress and Anxiety. International Journal of Saudi Journal of Business and Management Studies (SJBMS), 3(6), 623628.

Soelton, M., \& Oktapriatna, N. (2018). How Complaining Behaviors Effect on Performance in Government Industries?. International Journal of Saudi Journal of Business and Management Studies (SJBMS), 3(6), 623628.

Soelton, M., \& Rakasidhi, J. (2018). How to Implementation Organization Citizenship Behaviors with performance on Accident insurance service. European Journal of Business and Management (EJBM), 10(15), 10-16.

Soelton, M., Pebriani, P., Umar, M., Triwulan, J., \& Wilantara, J. How transformational leadership, communication, and workload on the employee performance affect shoes industries. South East Asia Journal of Contemporary Business, Economics and Law, Vol. 17, Issue 5(December) ISSN 2289-1560

Soelton, M., Nugrahati, T., Setiawan, M., Rohman, F., \& Pratama, A. (2019). Gender: Stress Levels On Performance In Modern Industry. Archives of Business Research, 7(2).

Soelton, M., \& Atnani, M. (2018). How Work Environment, Work Satisfaction, Work Stress On The Turnover Intention Affect University Management. Jurnal Manajemen dan Bisnis Indonesia, 5(3), 439-448.

Soelton, M., Umar, M. (2018). Recognizing How The Time Demands of Work Influences the Turn Over Intention in Banking Industry. European Journal of Business and Management (EJBM), 12 (19).

Saranya, Kamala. (2014). Influence of Job Satisfaction on Employee's Performance - A General Perspective, Vol.2 (2).

Schein, Edgar, H. (2010), Organizational Culture and Leadership, San Fransisco, Calif : Jossey-Bass Publisher.

Sugiyono.(2017). Metode Penelitian Bisnis.Bandung : Alfabeta.

Suhendi, H \& Anggara, S (2010). Perilaku Organisasi. Bandung: CV Pustaka Setia.

Suifan, T.S. (2016). The Impact of Organizational Climate and PsychologicalCapital on Organizational Citizenship Behaviour. International Journal of Business and Management, 11 (1), 224-230, DOI : 10.5539/ijbm.vllnlp.

Sunyoto, D. \& Burhanudin. (2011). Perilaku Organisasional, edisi pertama, CAPS, Yogyakarta.

Susanti, E. (2012). Pengaruh Iklim Organisasi terhadap Kepuasan Kerja dan Komitmen Karyawan pada Universitas Terbuka. Jurnal Organisasi dan Manajemen, 8 (2), 121-134.

Sutrisno, E. (2017). ManajamenSumberDayaManusia. Edisi 9, Kencana, Jakarta.

Sutrisno, Edy. (2011). Manajemen Sumber Daya Manusia. Jakarta :Kencana.

Tagiuri, R. \&Litwin, G. (1968).Organizational Climate : Expectations of a Concept. Boston :Hardvard University Press.

Titisari, Purnamie. (2014). Peranan Organizational Citizenship Behaviour (OCB) Dalam Meningkatkan Kinerja Karyawan, Mitra Wacana Media, Jakarta

Wibisino, A. (2011) Pengaruh Iklim Organisasi terhadap Kepuasan Kerja studi tentang Pengaruh Iklim Organisasi terhadap Kepuasan Kerja Pegawai Puskesmas Turen di Malang. Jurnal Aplikasi Manajemen, 9 (3), 10001010 . 